\title{
What Impact Have SARS-CoV-2/Covid-19 Pandemic on domestic violence against women in India across different states and union territories from the beginning of lockdown due to covid-19 pandemic in March 2020 till $20^{\text {th }}$ September 2020? How Covid-19 pandemic induced lockdown influence mental health of women in India?
}

Dr Piyush Kumar ( $\sim$ drpiyush003@gmail.com)

Bihar Health Department, Government of Bihar https://orcid.org/0000-0001-9857-478X

Research Article

Keywords: SARS-CoV-2, pandemic, violence, women, lockdown, domestic abuse

Posted Date: April 14th, 2021

DOI: https://doi.org/10.21203/rs.3.rs-414848/v2

License: () (1) This work is licensed under a Creative Commons Attribution 4.0 International License. Read Full License 


\section{Abstract}

Background: The protection of women is of utmost importance and prime concern in India due to a huge population, equity issues, gender issues, lack of positive deviance at community level, illiteracy, socio-economic factors, migration from rural to urban areas, inaccessibility to legal help and of course many more factors. The SARS-CoV-2 pandemic had presented a challenge even for developed nations around the world regarding women's protection in the ongoing pandemic era \& especially in the lockdown period when it's really difficult to go out and shout for help. Estimates published by WHO indicate that globally about 1 in $3(30 \%)$ of women worldwide have been subjected to either physical and/or sexual intimate partner violence or non-partner sexual violence in their lifetime. Lockdowns during the COVID-19 pandemic and its social and economic impacts have increased the exposure of women to abusive partners and known risk factors, while limiting their access to services. Situations of humanitarian crises and displacement may exacerbate existing violence, such as by intimate partners, as well as non-partner sexual violence, and may also lead to new forms of violence against women. ${ }^{1}$

Objectives: The main aim of this research is to find out Impact of SARS-CoV-2/Covid-19 Pandemic on domestic violence against women in India across different states and union territories from the beginning of lockdown due to covid-19 pandemic. Data from March $\mathbf{2 0 2 0}$ till $\mathbf{2 0}$ th September $\mathbf{2 0 2 0}$ is available so the study will give detail for this period. Settings \& Design: The month-wise and state-wise data indicating number of complaints registered with National Commission for Women in India(NCW) under two different categories in two different table $1 \& 2$ will be discussed and displayed. The period of study is from March 2020 to $20^{\text {th }}$ september2020.

Materials \& Methodology: The press information bureau ${ }^{2}$, Government of India Ministry of Women and child development have publicly announced under the heading- Increase in domestic violence against women dated 22 Sep 2020. The data obtained is analysed by using Microsoft Office software.

Result: Increase in domestic violence against women in India from March 2020 till $20^{\text {th }}$ September 2020. See Figure 1:- comparison of number of cases of domestic violence to know the impact of SARS-CoV-2 pandemic and lockdown situations in India.

Conclusion: India should have various strategies to ensure safety of women and their mental health issues in such pandemic like situations. It seems that present laws and regulations are insufficient to give the desired results. The barriers of legal and protective system and delivery of helpful services etc. constraints should be rectified added with a proper dynamic plan to carry on usual women protection services even in pandemics and natural disasters. India needs to develop an exclusive plan to tackle such situations such as establishment of separate cadre of worker for women protection services. India is having a very huge population of women's vulnerable to different kinds of violence so the Government must give top priority in making India a safe place for women's. The domestic violence have a serious impact on mental health of women's and their children especially in pandemic and lockdown situations in which its quite difficult to get help and relief.

\section{Introduction}

The protection of women is of utmost importance and prime concern in India due to a huge population, equity issues, lack of positive deviance at community level, illiteracy, socio-economic factors, migration from rural to urban areas, inaccessibility to legal help and of course many more factors. The SARS-CoV-2 pandemic had presented a challenge even for developed nations around the world regarding women's protection in the ongoing pandemic era \& especially in the lockdown period when it's really difficult to go out and shout for help.

The police force and other protective forces have been largely deployed to tackle the situation of pandemic of Covid-19. This shift has tremendous effect on ongoing various violence against women's in the pandemic era. Pregnant mother \& children's are especially more vulnerable groups. The women's usually have a sense of fear in meeting others particularly in pandemic acute emergency situations. Moreover most of the women's have to stay in home due to lockdown enforcement and added to this as per protocols the community and system both have constrains erupting from the sudden situations of pandemic. The mental health of women's having violence as well as workload with social-issues is a major concern globally added to income loss and various socioeconomic determinants of health. Loss of jobs, stress, reduced income, lockdown, violence, domestic conflicts and several other factors related to daily livelihood creates a vicious cycle and the women gets entangled in this cycle particularly in pandemic and lockdown situations.

The advocacy for maternal health, women empowerment have been done and emphasised by many national and international organisation for several decades considering them especially vulnerable groups in times of disaster such as pandemic. The Covid-19 pandemic has clearly disclosed the weakness of protective system to protect above mentioned vulnerable groups. The situation also produced a demand of separate cadre to protect women in situations of disaster like pandemic. It seems many protective services were not delivered in covid-19 era which may produce undesirable and detrimental effects at mass level in coming future.

\section{OBJECTIVES}

Domestic abuse, also called "domestic violence" or "intimate partner violence", can be defined as a pattern of behaviour in any relationship that is used to gain or maintain power and control over an intimate partner. Abuse is physical, sexual, emotional, economic or psychological actions or threats of actions that influence another person. This includes any behaviour that frightens, intimidate, terrorize, manipulate, hurt, humiliate, blame, injure, or wound someone. Domestic abuse can happen to anyone of any race, age, sexual orientation, religion, or gender. It can occur within a range of relationships including couples who are married, living together or dating. Domestic violence affects people of all socioeconomic backgrounds and education levels. ${ }^{3}$

The main aim of this research is to find out Impact of SARS-CoV-2/Covid-19 Pandemic on domestic violence against women in India across different states and union territories from the beginning of lockdown due to covid-19 pandemic. Data from March 2020 till $20^{\text {th }}$ September 2020 is available so the study will give detail for this period. See table 1, 2, 3 \& figure 1. 


\section{Materials And Methodology}

The national commission for women (NCW) in India have launched an Ad campaign from the beginning of the lockdown in March 2020. The lockdown was announced on $24^{\text {th }}$ march 2020 for 21 days. Various Ads through electronic as well as social media were instituted to know about the women's who have suffered any kind of violence to come forward and report to concerned department and authorities in several ways.

The NCW had also launched a whatsapp number as well as helpline number for reporting domestic violence situations in addition to other previously established chains of communications. The received complaints were duly addressed by concerned department and authorities. The complaints received were recorded in two headings as shown in table 1 and table2. Table 1 category includes protection of women against domestic violence received from March 2020 till $20^{\text {th }}$ September 2020. Table 2 includes total complaints registered / received by NCW related to crime against women as well as deprivation of their rights since March 2020 till 20 ${ }^{\text {th }}$ September 2020. Also see table 3 \& figure 1.

\section{Settings \& Design:}

The month-wise and state-wise data indicating number of complaints registered with National Commission for Women in India(NCW) under two different categories in two different table $1 \& 2$ will be discussed and displayed. The period of study is from March 2020 to $20^{\text {th }}$ september2020. The data is compared to previous year 2019 data.

The data is also shown in tabulated as well as graphical form for ease of understanding. All the data obtained were analysed using Microsoft office software. The analysis report is presented as graphs and also in letters. See table 1, 2, 3 \& figure 1.

\section{Methodology}

All the data obtained were analysed using Microsoft office software. The analysis report is presented as graphs and also in letters. The data for analysis is obtained from the source mentioned below in reference.

\section{Results}

Increase in domestic violence against women in India from March 2020 till $20^{\text {th }}$ September 2020 . The total number of State-wise and month-wise data indicating number of complaints registered with NCW under the category "Protection of Women against domestic violence", received during the last six months, i.e. from March 2020 till 18th September, 2020- is 4350 (Uttar Pradesh reported maximum). Total number of Month-wise and State-wise data of complaints registered/ received by NCW since March 2020 is 13410 (Uttar Pradesh reported maximum). The data is compared to NCRB (national crime record bureau) data $2019^{4}$ the total number of female victim of domestic violence was 554 \& total number of incidence was 553 and the crime rate $0.1 \%$ per lakh population - See table 1, 2, 3 \& figure 1

Lockdowns during the COVID-19 pandemic and its social and economic impacts have increased the exposure of women to abusive partners and known risk factors, while limiting their access to services. Situations of humanitarian crises and displacement may exacerbate existing violence, such as by intimate partners, as well as non-partner sexual violence, and may also lead to new forms of violence against women. ${ }^{5}$

\section{Discussion}

India should have various strategies to ensure safety of women in such pandemic like situations. It seems that present laws and regulations are insufficient to give the desired results. The barriers of legal and protective system and delivery of helpful services etc. constraints should be rectified added with a proper dynamic plan to carry on usual women protection services even in pandemics and natural disasters. India needs to develop an exclusive plan to tackle such situations such as establishment of separate cadre of worker for women protection services. India is having a very huge population of women's vulnerable to different kinds of violence so the Government must give top priority in making India a safe place for women's. The women's who are illiterate must not have access to all these reporting system as well as women from poor economical background added with remote village areas with less communication mechanisms.

Over a quarter of women aged15-49 years who have been in a relationship have been subjected to physical and/or sexual violence by their intimate partner at least once in their lifetime (since age 15). The prevalence estimates of lifetime intimate partner violence range from $20 \%$ in the Western Pacific, $22 \%$ in highincome countries and Europe and 25\% in the WHO Regions of the Americas to 33\% in the WHO African region, 31\% in the WHO Eastern Mediterranean region, and $33 \%$ in the WHO South-East Asia region. Worldwide as many as $38 \%$ of women murders are committed by intimate partners, in addition to this partner violence, globally $6 \%$ of women report having been sexually assaulted by someone other than a partner, although data for non-partner sexual violence are more limited. Intimate partner and sexual violence are mostly perpetrated by men against women. ${ }^{6}$

The domestic violence has much impact on mental health status of women and children's. The lockdown and pandemic era have developed a sense of fear among the women's. The fear can lead to self harm such as suicide etc. and added to this there is loss of income which has many serious socio-economic impacts resulting in a vicious cycle finally leading to mental health issues.

\section{Conclusion}

- Establishment of exclusive special women protection cell in disaster like pandemic situations at central level as well as at all the states and union territories of India. 
- Covid-19 pandemic has given us a lesson that we must have gender equity in society\& women's who are considered most vulnerable in situations of distress must have adequate supportive protection all the times especially during pandemics and other natural calamities. Women constitute a large portion of population and the country and state must have a separate department to ensure the protection to this vulnerable section of the population.

- India being the second most populous country in the world should have a robust women protection strategy to operate in any situations.

- The serious issue of mental health as well as socio-economic impacts of violence and lockdown should be properly taken care in pandemic like situation to protect especially vulnerable women's as well as their children's.

\section{Declarations}

This paper has not been previously published and is not currently under consideration by another journal. The document is Microsoft word with English (India) language \& 3967 words Total.

- Ethics approval and consent to participate: Not applicable. This study has not involved any human or animals in real or for experiments

-Consent for publication: Not applicable

-Availability of data and materials: The data \& materials source is well listed in reference below.

\section{-Conflicts of Interest/ Competing Interest}

There are no conflicts / competing of interest

- Funding-Self sponsored. No aid taken from individual or agency etc.

- Authors' contributions: The whole work is solely done by the Author - Dr Piyush Kumar, M.B.B.S. - Sri Krishna Medical College, EMOC-PMCH General Medical Officer- Bihar Health Services- Government of Bihar, India.

Acknowledgements- I am thankful to advocate Anupama my wife for cooperation.

- Author information: The author is currently working as general medical officer for the government of Bihar.

-Financial Support \& sponsorship: Nil

\section{References}

1 https://www.who.int/news-room/fact-sheets/detail/violence-against-women

2 https://pib.gov.in/indexd.aspx

3 https://www.un.org/en/coronavirus/what-is-domestic-abuse

4 https://ncrb.gov.in/

5 https://www.who.int/news-room/fact-sheets/detail/violence-against-women

6 https://www.who.int/news-room/fact-sheets/detail/violence-against-women

\section{Tables}

Table 1- The State-wise and month-wise data indicating number of complaints registered with NCW under the category "Protection of Women against domestic violence”, received during the last six months, i.e. from March 2020 till 18th September, 2020-

Source- https://pib.gov.in/allRel.aspx 


\begin{tabular}{|c|c|c|c|c|c|c|c|c|c|c|}
\hline S.N & oState & Mar & hAp & $1 \mathrm{Ma}$ & yJune & eJuly & yAug & September & Received through Whasapp & $\rho^{\text {Total }}$ \\
\hline 1 & Andhra Pradesh & 1 & 2 & 1 & 1 & 5 & 4 & 3 & 13 & 30 \\
\hline 2 & Assam & 4 & 6 & 3 & 2 & - & 2 & - & 14 & 31 \\
\hline 3 & Bihar & 6 & 20 & 31 & 31 & 43 & 29 & 16 & 78 & 254 \\
\hline 4 & Chandigarh & - & 1 & 1 & 3 & - & 1 & - & 2 & 8 \\
\hline 5 & Chhattisgarh & 3 & 5 & 1 & 4 & 3 & 5 & 1 & 12 & 34 \\
\hline 6 & Dadar\&Nagar Haveli & i. & - & - & - & - & 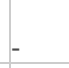 & - & 4 & 4 \\
\hline 6 & Delhi & 63 & 60 & 94 & 76 & 119 & 9115 & 76 & 181 & 784 \\
\hline 7 & Goa & 1 & 1 & - & - & 1 & - & - & 2 & 5 \\
\hline 8 & Gujarat & 6 & 4 & 6 & 11 & 2 & 8 & 1 & 17 & 55 \\
\hline 9 & Haryana & 22 & 13 & 15 & 27 & 41 & 19 & 17 & 75 & 229 \\
\hline 10 & Himachal Pradesh & 3 & 4 & 4 & 5 & 2 & 2 & 2 & 7 & 29 \\
\hline 11 & Jammu and Kashmir & 1 & 1 & 2 & 6 & 3 & 3 & - & 6 & 22 \\
\hline 12 & Jharkhand & 6 & 6 & 7 & 12 & 9 & 10 & 4 & 33 & 87 \\
\hline 13 & Karnataka & 5 & 18 & 12 & 21 & 17 & 11 & 4 & 49 & 137 \\
\hline 14 & Kerala & 2 & 5 & 2 & 4 & 3 & 3 & 1 & 13 & 33 \\
\hline 15 & Madhya Pradesh & 4 & 17 & 7 & 16 & 36 & 18 & 5 & 46 & 149 \\
\hline 16 & Maharashtra & 17 & 45 & 60 & 59 & 56 & 56 & 22 & 143 & 458 \\
\hline 17 & Manipur & - & - & 1 & - & - & - & - & - & 1 \\
\hline 18 & Meghalaya & 1 & - & - & - & - & - & - & - & 1 \\
\hline 19 & Nagaland & - & - & - & - & - & - & - & 1 & 1 \\
\hline 20 & Odisha & 3 & 2 & 1 & 2 & 3 & 9 & 1 & 12 & 33 \\
\hline 20 & Pondicherry & - & - & - & 1 & - & - & - & - & 1 \\
\hline 21 & Punjab & 5 & 10 & 10 & 14 & 19 & 13 & 5 & 27 & 103 \\
\hline 22 & Rajasthan & 10 & 15 & 8 & 11 & 30 & 27 & 5 & 67 & 173 \\
\hline 23 & Tamil Nadu & 11 & 10 & 13 & 14 & 17 & 10 & 16 & 46 & 137 \\
\hline 24 & Telangana & 4 & 4 & 7 & 9 & 7 & 5 & - & 15 & 51 \\
\hline 25 & Tripura & - & - & - & - & - & - & - & 2 & 2 \\
\hline 26 & Uttar Pradesh & 110 & 47 & 85 & 110 & 208 & 3163 & 55 & 190 & 968 \\
\hline 27 & Uttarakhand & - & 3 & 3 & 6 & 12 & 13 & 3 & 11 & 51 \\
\hline
\end{tabular}




\begin{tabular}{|l|l|l|l|l|l|l|l|l|l|l|l|}
\hline 28 & West Bengal & 10 & 16 & 19 & 16 & 24 & 12 & 5 & 80 & 182 \\
\hline 28 & Miscellaneous & & & & & & & & 297 & 297 \\
\hline & Total & 298 & 315 & 393 & 461 & 660537 & 243 & 1443 & 4350
\end{tabular}

Table 2 - Month-wise and State-wise data of complaints registered/ received by NCW since March 2020 (till 20.09.2020)). Source- https://pib.gov.in/allRel.aspx 
1.

Andaman and Nicobar Islands

2. Andhra Pradesh ch April May June July August

September

(till 20.09.2020)

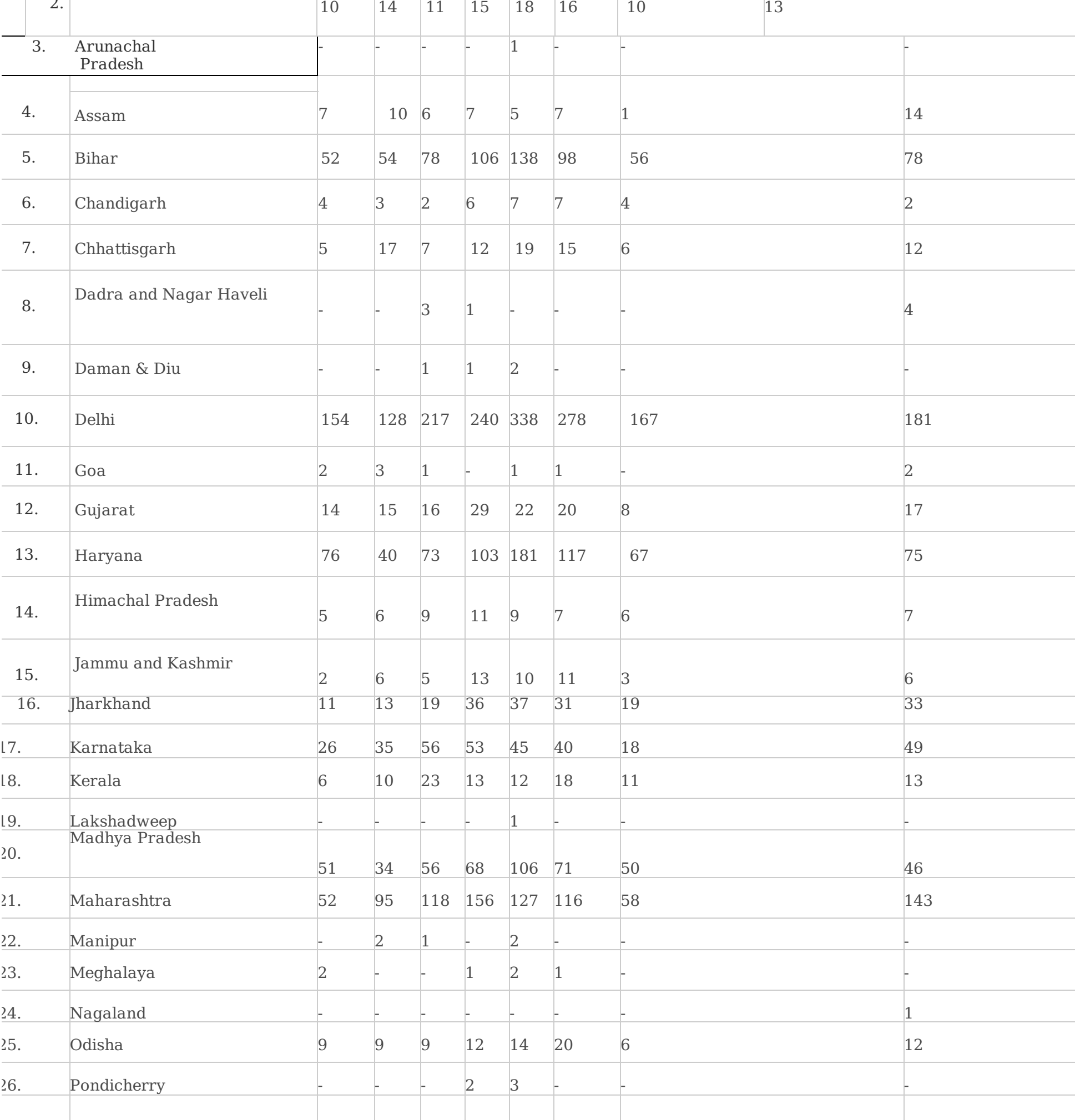




\begin{tabular}{|c|c|c|c|c|c|c|c|c|c|}
\hline 27. & Punjab & 21 & 26 & 42 & 37 & 56 & 48 & 25 & 27 \\
\hline 28. & Rajasthan & 48 & 39 & 83 & 82 & 118 & 96 & 40 & 67 \\
\hline 29. & Tamil Nadu & 32 & 27 & 46 & 64 & 47 & 41 & 39 & 46 \\
\hline 30. & Telangana & 17 & 10 & 20 & 23 & 22 & 19 & 8 & 15 \\
\hline 31. & Tripura & - & - & - & - & & 2 & - & 2 \\
\hline 32. & Uttar Pradesh & 699 & 159 & 530 & 876 & 1461 & 966 & 600 & 190 \\
\hline 33. & Uttarakhand & 17 & 9 & 21 & 33 & 55 & 41 & 15 & 11 \\
\hline 34. & West Bengal & 24 & 36 & 47 & 43 & 55 & 41 & 18 & 80 \\
\hline 35. & Miscellaneous & - & - & - & - & - & - & - & 297 \\
\hline 36. & Total & 1,347 & 800 & 1,50 & 02,043 & 32,914 & 42,128 & 1,235 & 1443 \\
\hline
\end{tabular}

Table 3- SLL Crimes against Women (Crime Head-wise \& State/UT-wise) - 2019- source- https://ncrb.gov.in/ 


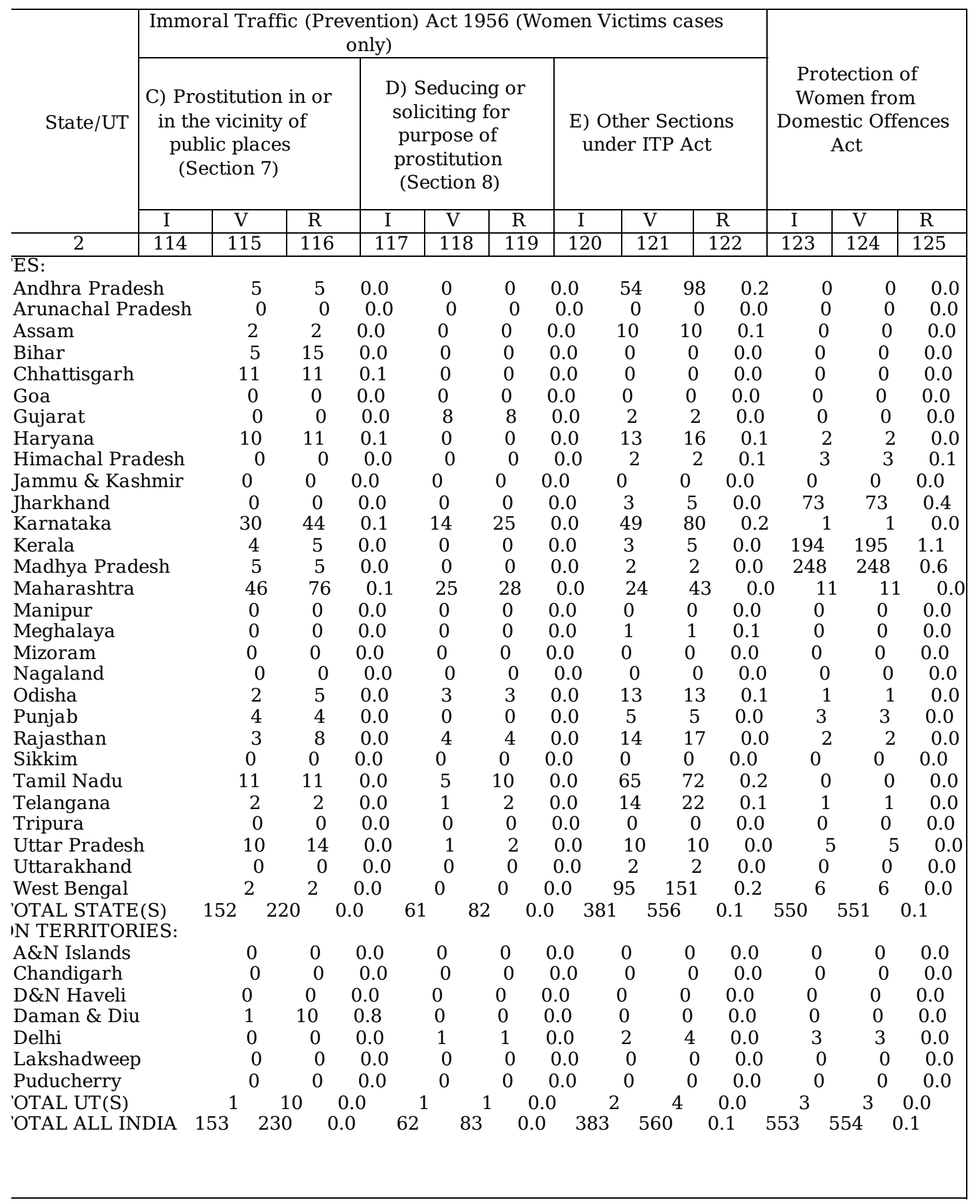

Due to non-receipt of data from West Bengal in time for 2019, Data furnished for 2018 Has been used ( $\mathrm{I}=$ No. of Incidences/Cases, $\mathrm{V}=$ No. of Female Victims \& $\mathrm{R}=$ Crime Rate Per lakh population) - source- https://ncrb.gov.in/

\begin{tabular}{|l|r|r|r|r|r|}
\hline year & number & & \\
\hline 2019 & 554 & & \\
\hline $2020 a$ & 4350 & & & \\
\hline & 13410 & & & \\
\hline & & & & \\
\hline & & & & \\
\hline & & & & \\
\hline & & & & \\
\hline
\end{tabular}




\section{Figure 1}

Comparison of number of cases of domestic violence to know the impact of SARS-CoV-2 pandemic and lockdown situations in India (please see description below figure and article text). 2019- See table 3 SLL Crimes against Women (Crime Head-wise \& State/UT-wise) - 2019 V= No. of Female Victims- sourcehttps://ncrb.gov.in/ 2020a- See Table 1- The State-wise and month-wise data indicating number of complaints registered with NCW under the category "Protection of Women against domestic violence", received during the last six months, i.e. from March 2020 till 18th September, 2020-Sourcehttps://pib.gov.in/allRel.aspx 2020b- See- Table 2 - Month-wise and State-wise data of complaints registered/ received by NCW since March 2020 (till 20.09.2020)). Source- https://pib.gov.in/allRel.aspx

\section{Supplementary Files}

This is a list of supplementary files associated with this preprint. Click to download.

- IncreaseinDomesticViolenceagainstWomen.pdf

- Table3A.22.pdf 